\title{
Exploring First Interactions Between Ostreid Herpesvirus 1 (OsHV-1) and Its Host, Crassostrea gigas: Effects of Specific Antiviral Antibodies and Dextran Sulfate
}

\section{Claire Martenot ${ }^{1 *}$, Nicole Faury ${ }^{1}$, Benjamin Morga ${ }^{1}$, Lionel Degremont ${ }^{1}$, Jean-Baptiste Lamy ${ }^{1}$, Maryline Houssin ${ }^{2}$ and Tristan Renault ${ }^{3}$}

${ }^{1}$ Institut Français de Recherche pour l'Exploitation de la Mer, Laboratoire de Génétique et Pathologie des Mollusques Marins, La Tremblade, France, ${ }^{2}$ LABEO, Saint-Contest, France, ${ }^{3}$ Département Ressources Biologiques et Environnement, Institut Français de Recherche pour l'Exploitation de la Mer, Nantes, France

Viral entry mechanisms of herpesviruses constitute a highly complex process which implicates several viral glycoproteins and different receptors on the host cell surfaces. This initial infection stage was currently undescribed for Ostreid herpes virus 1 (OsHV1), a herpesvirus infecting bivalves including the Pacific oyster, Crassostrea gigas. To identify OsHV-1 glyproteins implicated in the attachment of the virus to oyster cells, three viral putative membrane proteins, encoded by ORF 25, 41, and 72, were selected and polyclonal antibodies against these targets were used to explore first interactions between the virus and host cells. In addition, effects of dextran sulfate, a negative charged sulfated polysaccharide, were investigated on OsHV-1 infection. Effects of antiviral antibodies and dextran sulfate were evaluated by combining viral DNA and RNA detection in spat (in vivo trials) and in oyster hemolymph (in vitro trials). Results showed that viral protein encoded by ORF 25 appeared to be involved in interaction between OsHV-1 and host cells even if other proteins are likely implicated, such as proteins encoded by ORF 72 and ORF 41 . Dextran sulfate at $30 \mu \mathrm{g} / \mathrm{mL}$ significantly reduced the spat mortality rate in the experimental conditions. Taken together, these results contribute to better understanding the pathogenesis of the viral infection, especially during the first stage of OsHV-1 infection, and open the way toward new approaches to control OsHV-1 infection in confined facilities.

Keywords: OsHV-1, antiviral antibodies, dextran sulfate, interaction, Crassostrea gigas, infection

\section{INTRODUCTION}

Ostreid herpesvirus 1 (OsHV-1) has been a major threat to Pacific cupped oyster cultivation in Europe over the last decades, especially for French oyster farmers. This virus-assigned to the Herpesvirales order and to the Malacoherpesviridae familyinduced mortality of early life-stage oysters (Le Deuff and Renault, 1999; Davison et al., 2005, 2009). Mass mortality outbreaks among Pacific oysters, Crassostrea gigas, have been regularly reported throughout the world, and consequently dramatic losses in production were recorded, generating a decline in the oyster farming industry in several places. The conventional vaccination strategy appears inappropriate due to the lack 
of specific cell immunity in invertebrates. In addition, chemotherapy and immune stimulation are unsuitable to oyster cultivation in the open field, even if these approaches could be considered in closed environments such as hatcheries. Currently control measures based on restrictions of oyster movements by authorities, modification of cultural practices and resistance breeding constitute serious ways to limit virus propagation and to decrease mortality rates. For several years, OsHV-1 (GenBank accession no. AY509253, "reference" type) and variants had been detected during mortality outbreaks or without oyster mortality around the world, such as in France (Nicolas et al., 1992; Renault et al., 1994; Renault and Lipart, 1998; Le Deuff and Renault, 1999; Garcia et al., 2011; Martenot et al., 2011, 2015), Ireland (Lynch et al., 2012; Peeler et al., 2012; Clegg et al., 2014), Spain (Da Silva et al., 2008; Aranguren et al., 2012; Roque et al., 2012), Italy (Dundon et al., 2011; Domeneghetti et al., 2014), Portugal (Batista et al., 2014), South Korea (Hwang et al., 2013; Jee et al., 2013), United States (Friedman et al., 2005; Burge et al., 2006, 2011), Mexico (Grijalva-Chon et al., 2013), Australia (Jenkins et al., 2013; Paul-Pont et al., 2013a,b, 2014), Brazil (Mello et al., 2018), and New Zealand (Renault et al., 2012; Bingham et al., 2013; Keeling et al., 2014; Whittington et al., 2015). Since 2008, a variant called $\mu$ Var has been mainly detected in French oyster samples and is characterized by 26 mutations in two regions of the viral genome: the $\mathrm{C}$ region (open reading frame (ORF) 4/5) and an IAP region (ORF 42/43) (Segarra et al., 2010; Martenot et al., 2011; Renault et al., 2012). Investigations performed over the last decades illustrated the efforts to better characterize OsHV-1 genetic diversity and its geographical distribution (Renault et al., 2012; Martenot et al., 2013, 2015; Burioli et al., 2016, 2017, 2018; Bai et al., 2017, 2019; Abbadi et al., 2018). Other studies focused on the OsHV-1 replication cycle by analyzing viral gene expression during an experimental OsHV-1 infection or in vitro approaches (Renault et al., 2011; Jouaux et al., 2013; Rosani et al., 2014; Segarra et al., 2014b; Morga et al., 2017). This knowledge was completed by recent results on tissue distribution of viral DNA, RNA and proteins (Schikorski et al., 2011a; Corbeil et al., 2015; Martenot et al., 2016; Segarra et al., 2016). Special interest is also given to host response to OsHV-1 infection by notably investigating relative expression of immune oyster genes (Renault et al., 2011; Jouaux et al., 2013; Rosani et al., 2014; Segarra et al., 2014a,b; Green et al., 2015; Morga et al., 2017; Green and Speck, 2018). The lack of bivalve cell lines complicates the understanding of the OsHV-1 infection mechanism and particularly interactions between the virus and its host cells. The present study attempts to better understand these interactions at protein level by approaches not already used in this model.

Polyclonal antibodies against three viral putative membrane proteins were incubated separately or in combination with OsHV-1 before injection of viral suspension in the adductor muscle of spat (in vivo trials) or before contact with hemolymph from adult oysters (in vitro trials). Viral membrane proteins play a major role in the earliest stage of infection during attachment and entry of the virus into host cells. The objective of incubating antiviral antibodies and OsHV-1 was to block potential viral proteins involved in molecular interactions between both partners and consequently to give new information about the first step of viral infection.

In addition, a sulfated polysaccharide negatively charged, dextran sulfate, was tested using a similar protocol. Dextran sulfate was selected since this molecule has a broad spectrum of antiviral activity against enveloped viruses such as herpes simplex virus (HSV), human cytomegalovirus, and vesicular stomatitis virus (Baba et al., 1988). Piret et al. (2000) demonstrated an inhibitor effect of dextran sulfate against various HSV-1 and HSV-2 strains by preventing binding of HSV to cell surface receptors and therefore their entry into cells. In the 1990s, several studies aiming to find new treatments to control Human Immunodeficiency Virus type 1 (HIV) infection showed that dextran sulfate interfered with membrane glycoprotein gp120 of HIV envelope and CD4 T lymphocytes (Bagasra and Lischner, 1988; Nakashima et al., 1989; Schols et al., 1990; Callahan et al., 1991). This effect was attributed to an inhibition of virus adsorption to host cell membrane (Baba et al., 1988). Due to potential inhibitor effects on enveloped viruses, this way was explored for OsHV-1 infection by combining in vitro and in vivo approaches.

\section{MATERIALS AND METHODS}

\section{Antiviral Antibody Production}

Three OsHV-1 proteins encoded by ORFs 25, 41, and 72 and identified as putative membrane proteins by Davison et al. (2005), were selected for antiviral antibody production since they may correspond to structural proteins located on the surface of the viral envelope, and therefore play a key role in interaction between OsHV-1 and its host cells. This interaction especially occurs in the earliest stage of infection during attachment and entry of the virus into cells.

Polyclonal antibodies targeting proteins encoded by ORFs 25, 41, and 72 were produced by ProteoGenix (Schiltigheim, France) at $1 \mathrm{mg} / \mathrm{mL}$. Briefly, the partial cDNA of each ORF was cloned in the pET-43.1a vector to express the protein with His tag in N-terminal position (cloning strategy: Ndel/XhoI). After purification of the three recombinant proteins, each one was then injected into rabbits. Polyclonal antibodies were separately purified using protein A affinity chromatography.

Polyclonal antibodies targeting proteins encoded by ORFs 25 and 72 were previously used by Martenot et al. (2016) to describe localization and tissue distribution of OsHV-1 proteins during an experimental OsHV-1 infection.

\section{Preparation of Oyster Tissue Homogenates}

Tissue suspensions were prepared from experimentally infected or uninfected spat, according to the protocol developed by Schikorski et al. (2011a; 2011b). Two hundred microliters ( $\mu \mathrm{L})$ were sampled for DNA extraction and real time polymerase chain reaction (PCR) analysis to quantify viral DNA in tissue homogenates. Tissue homogenate positive and negative for viral DNA detection was called "viral suspension" and "control suspension," respectively. A total of $100 \mu \mathrm{L}$ was plated onto 
Zobell agar and incubated for 2 to 3 days at $22^{\circ} \mathrm{C}$ to control for the absence of bacteria in suspensions.

\section{Contact Between Preparation of Viral Suspension and Antiviral Antibodies or Dextran Sulfate}

Viral suspension was directly used for in vivo and in vitro assays at $10^{5}$ viral DNA copies per $\mu \mathrm{L}$ or after an incubation period with antiviral antibodies or dextran sulfate before use.

Polyclonal antiviral antibodies $(1 \mathrm{mg} / \mathrm{mL})$ were incubated separately (30 $\mu \mathrm{L}$ of anti-ORF 25 or $30 \mu \mathrm{L}$ of anti-ORF 41 , or $30 \mu \mathrm{L}$ of anti-ORF 72$)$ or in combination $(10 \mu \mathrm{L}$ of anti-ORF 25 , $10 \mu \mathrm{L}$ of anti-ORF 41 , and $10 \mu \mathrm{L}$ of anti-ORF 72) with $1 \mathrm{~mL}$ of viral suspension.

A control was performed using a green fluorescent protein (GFP) Tag polyclonal antibody (A11122, Life Technologies) to determine the specificity of the effect induced by antiviral antibodies. As GFP antibody was concentrated at $2 \mathrm{mg} / \mathrm{mL}, 15 \mu \mathrm{L}$ of this antibody were added to $1 \mathrm{~mL}$ of viral suspension.

A stock solution of dextran sulfate (1020-A, Euromedex) concentrated at $5 \mathrm{mg} / \mathrm{mL}$ was performed in artificial seawater (ASW) sterilized by autoclaving and filtered at $0.22 \mu \mathrm{M}$. This solution was then diluted in viral suspension to obtain a final concentration of 30 or $300 \mu \mathrm{g} / \mathrm{mL}$.

All prepared suspensions with antiviral antibodies and dextran sulfate were incubated at $4^{\circ} \mathrm{C}$ overnight under gentle stirring.

\section{In vivo Trials: Biological Material and Experimental Infection}

Crassostrea gigas spat produced in 2014 at the Ifremer hatchery located in Argenton (Brittany, France) and then reared at Ifremer facilities in Bouin (Vendée, France) were used for experimental infections by OsHV-1. The viral challenge was performed according to the protocol developed by Schikorski et al. (2011a, b). Briefly, spat were put in a myorelaxing solution containing magnesium chloride to open their valves before injecting suspension in the adductor muscle. Sixty spat (15 spat per tank) were used for each tested condition: viral suspension, viral suspension incubated with $30 \mu \mathrm{g} / \mathrm{mL}$ of dextran sulfate and viral suspension incubated with three anti-viral antibodies (in combination). Twenty spat distributed in 2 tanks (10 spat per tank) were used for each control: viral suspension incubated with anti-GFP antibodies ( $n=20)(1)$, suspension prepared from uninfected spat incubated with dextran sulfate at $30 \mu \mathrm{g} / \mathrm{mL}$ $(n=20)$ (2), suspension prepared from uninfected spat incubated with antibody buffer $(n=20)$ (3), viral suspension incubated with the antibody buffer $(n=20)(4)$, and sterilized ASW $(n=20)$ (5). Control 1 aimed to validate the anti-viral specific effect in comparison to those obtained with anti-GFP antibodies. Controls 2,3 , and 4 aimed to ensure that dextran sulfate and antibody buffer did not induce oyster mortality or a degradation of viral particles, respectively. Control 5 was performed to ensure that spat mortality was specific to the injected suspension. After injection of suspensions in the adductor muscle, oysters were then placed in tanks containing $5 \mathrm{~L}$ of filtered seawater and kept in controlled conditions at $22^{\circ} \mathrm{C}$ without food supply.
Mortality was monitored three times per day during 1 week after intramuscular injection. Dead spat were collected and stored at $-20^{\circ} \mathrm{C}$ for DNA extraction and OsHV-1 DNA quantification by real-time PCR.

\section{In vitro Trials}

In vitro assays were performed by incubating hemolymph with viral suspension according to the protocol developed by Morga et al. (2017). For the present work, an important hemolymph volume was requisited and consequently hemolymph from C. gigas adults were used to realize in vitro trials. In this context, OsHV-1 replication was firstly investigated using hemolymph collected from six oyster families produced from two different genetic backgrounds (hereafter named from A to F). Four of them were unselected families (families A, B, C, and E) and the two others were selected for their higher resistance to OsHV-1 infection (families D and F). Oysters from families A to D shared the same genetic background whereas oysters from families $\mathrm{E}$ and $\mathrm{F}$ shared another genetic background. Their susceptibility to OsHV-1 infection was tested under experimental infection by cohabitation as well as in field condition (Table 1). Mortality rates were associated with high OsHV-1 DNA concentrations (data not shown). Due to the low amounts of oysters in families $\mathrm{A}, \mathrm{B}$, and $\mathrm{C}$, and as they shared same genetic background and demonstrated a similar susceptibility to OsHV-1 infection in experimental challenges, hemolymph from these three family oysters was gathered to perform some in vitro trials.

After cutting the edge of the oyster shell, hemolymph was collected from adductor muscle using a $1 \mathrm{ml}$ syringe equipped with a needle $(0.60 \mathrm{~mm} \times 32 \mathrm{~mm})$. Hemolymph collected from several oysters of a same family was pooled together and then filtered through a nylon grid of $70 \mu \mathrm{m}$ (352350, Dutcher) to eliminate large particles. Hemolymph was held on ice before use to limit cell aggregation.

A total of $200 \mu \mathrm{L}$ and $1.7 \mathrm{~mL}$ of hemolymph pool was sampled for OsHV-1 DNA and RNA detection, respectively.

For the in vitro assay, $1.7 \mathrm{~mL}$ of hemolymph, $119 \mu \mathrm{L}$ of an antibiotic mix filtered at $0.22 \mu \mathrm{m}(4 \mathrm{mg} / \mathrm{mL}$ of streptomycin, $11.6 \mathrm{mg} / \mathrm{mL}$ of penicillin, $5.1 \mathrm{mg} / \mathrm{mL}$ of neomycin, $3.3 \mathrm{mg} / \mathrm{mL}$ of erythromycin, $0.1 \mu \mathrm{L} / \mathrm{mL}$ of nystatin), and $850 \mu \mathrm{L}$ of a viral suspension concentrated at $10^{5}$ viral DNA copies $/ \mu \mathrm{L}$ were added in an Eppendorf $5 \mathrm{~mL}$ tube. A negative control was performed by replacing viral suspension with $850 \mu \mathrm{L}$ of sterilized ASW. They were incubated at $19^{\circ} \mathrm{C}$ under gentle shaking during $0,2,4,6$, and

TABLE 1 | Mortality rates reported in the field and in experimental challenges with OsHV-1 for the six oyster families.

\begin{tabular}{lcc}
\hline Oyster families & $\begin{array}{c}\text { Mortality rate } \\
\text { (field) }\end{array}$ & $\begin{array}{c}\text { Mortality rate } \\
\text { (experimental Challenge) }\end{array}$ \\
\hline A & $71 \%$ & $86 \%$ \\
B & $89 \%$ & $85 \%$ \\
C & $63 \%$ & $85 \%$ \\
D & $41 \%$ & $31 \%$ \\
E & $79 \%$ & $98 \%$ \\
F & $11 \%$ & $11 \%$
\end{tabular}


18 h. Four replicates were performed: two replicates for OsHV-1 DNA analysis and two replicates for OsHV-1 RNA analysis. After the incubation period, samples were centrifuged at $1,500 \times \mathrm{g}$ for $10 \mathrm{~min}$ at $4^{\circ} \mathrm{C}$ to obtain hemocyte pellets and the supernatant was removed. For viral DNA investigation, samples were stored at $-20^{\circ} \mathrm{C}$. For viral RNA analysis, $1 \mathrm{~mL}$ of TRIZOL ${ }^{\circledR}$ Reagent $^{\mathrm{TM}}()$ was added to the hemocyte pellet on ice and mixed fore few minutes, to be stored later at $-80^{\circ} \mathrm{C}$.

The effect of the three polyclonal antiviral antibodies and dextran sulfate was tested with the protocol described above. Hemolymph from adult oysters was added to a viral suspension incubated with antiviral antibodies or anti-GFP antibodies or dextran sulfate overnight at $4^{\circ} \mathrm{C}$.

\section{Molecular Analysis \\ OsHV-1 DNA Detection}

DNA was extracted from the mantle of dead spat sampled during OsHV-1 experimental infection (in vivo trials) with the QIAmp DNA mini Kit (Qiagen) according to the manufacturer's instructions. DNA concentrations and quality were then measured using a NanoDrop spectrophotometer (Thermo Fisher Scientific). DNA was diluted at $5 \mathrm{ng} / \mu \mathrm{L}$, and $5 \mu \mathrm{L}$ of this solution was used to perform real time PCR analysis. The same DNA extraction protocol was used for hemocyte pellets collected during in vitro assays. Elution was performed in $50 \mu \mathrm{L}$ of water for molecular biology, and $5 \mu \mathrm{L}$ was directly used for real time PCR analysis.

As dextran sulfate caused PCR inhibition, another DNA extraction protocol was used for hemolymph incubated with this molecule. Magnetic beads of the NucliSENS ${ }^{\circledR}$ easyMAG ${ }^{\circledR}$ kit (Biomerieux, France) were used to capture DNA and eliminate PCR inhibitors. Elution was performed in $50 \mu \mathrm{L}$ of elution buffer, and $5 \mu \mathrm{L}$ was directly used for real time PCR analysis.

OsHV-1 DNA quantification was performed with realtime PCR based on TaqMan ${ }^{\circledR}$ chemistry targeting a putative apoptosis inhibitor (Martenot et al., 2010). Briefly, $5 \mu \mathrm{L}$ of DNA was added to the reaction mixture composed of $10 \mu \mathrm{L}$ of Brilliant III Ultra-Fast QPCR Master Mix (Agilent Technologies), $0.4 \mu \mathrm{L}$ of each primers $(20 \mu \mathrm{M})$ OsHV1BF (forward) $5^{\prime}$-GTCGCATCTTTGGATTTAACAA-3' and B4 (reverse) $5^{\prime}$ ACTGGGATCCGACTGACAAC- $3^{\prime}, 0.4 \mu \mathrm{L}$ of TaqMan ${ }^{\circledR}$ probe $(10 \mu \mathrm{M}) 5^{\prime}$-TGCCCCTGTCATCTTGAGGTATAGACAATC-3', and $3.8 \mu \mathrm{L}$ of distilled water. Amplification was performed in duplicate for each sample and accomplished using a Mx3000P real-time PCR thermocycler (Agilent). PCR conditions were 1 cycle at $95^{\circ} \mathrm{C}$ for $3 \mathrm{~min}, 40$ cycles of amplification at $95^{\circ} \mathrm{C}$ for $10 \mathrm{~s}$, and $60^{\circ} \mathrm{C}$ for $20 \mathrm{~s}$. Assays included a standard curve and a negative control (5 $\mu \mathrm{L}$ of distilled water instead of the $5 \mu \mathrm{L}$ of sample DNA). Results were expressed in viral DNA copies in one nanogram of total DNA for oyster tissue samples or in extracted DNA volume for hemocyte pellets.

\section{Oyster and OsHV-1 RNA Quantification}

Total RNA was extracted using the Ambion ${ }^{\circledR}$ TRIZOL $^{\circledR}$ Reagent $^{\mathrm{TM}}$ (Life Technologies, Saint-Aubin, France) according to the manufacturer's recommendations. RNA quality and amount were controlled with NanoDrop spectrophotometer (Thermo Fisher Scientific). A DNase treatment was performed with the Ambion $^{\circledR}$ TURBO DNA-free ${ }^{\mathrm{TM}}$ (Life Technologies) according to the manufacturer's instructions. A second RNA extraction was then realized using TRIZOL $^{\circledR}$ Reagent $^{\text {TM }}$ to inhibit and eliminate the DNase.

A No RT (Reverse Transcription) was systematically performed after each DNAse treatment by real time PCR $\left(\mathrm{SYBR}^{\circledR}\right.$ Green chemistry) targeting the oyster elongation factor alpha (EF1 alpha) to control absence of oyster and virus genomic DNA. Five microliters of DNAse-treated RNA were added to the reaction mixture composed of $10 \mu \mathrm{L}$ of Brilliant III ultra-Fast SYBR $^{\circledR}$ Green Master Mix 10X (Agilent Technologies), $2 \mu \mathrm{L}$ of each primer concentrated at $1.5 \mu \mathrm{M}$, and $1 \mu \mathrm{L}$ of distilled water. Amplification was performed in duplicate for each sample and accomplished using a Mx3000P real-time PCR thermocycler (Agilent). PCR conditions consisted of 1 cycle at $95^{\circ} \mathrm{C}$ for $3 \mathrm{~min}, 40$ cycles of amplification at $95^{\circ} \mathrm{C}$ for $5 \mathrm{~s}, 60^{\circ} \mathrm{C}$ for $20 \mathrm{~s}$, and followed by a dissociation stage $\left(95^{\circ} \mathrm{C}\right.$ for $1 \mathrm{~min}, 60^{\circ} \mathrm{C}$ for $30 \mathrm{~s}$, and $95^{\circ} \mathrm{c}$ for $\left.30 \mathrm{~s}\right)$.

After RNA quantification, first-strand cDNA synthesis was carried out using the Super-Script ${ }^{\circledR}$ III First-Strand Synthesis System (Invitrogen) from $500 \mathrm{ng}$ of DNAse-treated RNA. Due to inhibition problems with dextran sulfate, reverse transcription was conducted on $50 \mathrm{ng}$ of DNAse-treated RNA for samples containing this molecule. A 1:30 dilution of the cDNA was realized and $5 \mu \mathrm{L}$ was used for PCR investigation.

Three viral genes encoding a putative membrane protein (ORF 72), a putative dUTPase (ORF 75) and a putative apoptosis inhibitor (ORF 87) were targeted to evaluate viral transcript production. These genes were selected on the basis of results reported by Morga et al. (2017) and Segarra et al. (2014a, b).

Viral gene expression levels were calculated for each sample with the following formula: [1 / $\left(\mathrm{Ct}\right.$ viral $\left.\left.\mathrm{ORF}-\mathrm{Ct}{ }_{\mathrm{EF}}\right)\right] \times 100$ (Morga et al., 2017).

\section{Statistical Analysis}

Data obtained from in vivo trials were analyzed with Generalized Linear Mixed Model (GLMM) to compare spat mortality between the different experimental conditions (Bolker et al., 2009).

Data obtained from in vitro trials were analyzed with the Shapiro-Wilk test and then a $t$-test (if the sample distribution was normal) or Mann-Whitney test (if normal distribution could not be demonstrated) by using XLSTAT-Pro ${ }^{\circledR} 2014.5 .03$ software (Addinsoft, Paris, France). This statistical analysis was performed to compare viral transcript numbers and viral DNA amounts obtained from one in vitro condition test (virus incubated with antiviral antibodies or dextran sulfate) to those obtained from the control condition (virus alone) and for each targeting ORF. This approach was also used to compare viral transcript numbers and viral DNA amounts between adult oysters presenting a high susceptibility to OsHV1 infection and adult oysters which are less susceptible to OsHV-1 infection. 


\section{RESULTS}

\section{Effect of Antiviral Antibodies or Dextran Sulfate on OsHV-1 Experimental Infection (in vivo Trials)}

As no spat mortality was recorded in different control conditions (sterilized ASW and antibodies buffer) and viral DNA copies per nanogram of total DNA in dead oysters were $\log 4.8 \pm 0.8$, mortality observed in tested conditions was considered to be due to viral infection (Figure 1). The final survival rate was significantly lower in positive control (viral suspension) in comparison to the virus incubated with the three antiviral antibodies $(p=0.0403)$ or with dextran sulfate $(p=0.0483)$ (Figure 1).

The specific effect of antiviral antibodies was investigated by a treatment of viral suspension with anti-GFP antibodies. Similar final mortality rates between positive control $(70 \% \pm 0 \%)$ and virus suspension incubated with anti-GFP antibodies $(75 \% \pm 7 \%)$ were reported.

\section{In vitro Protocol Validation With Hemolymph From Adult Oysters} OsHV-1 DNA Detection in Hemolymph Collected From Adult Oysters With Different Susceptibility to OsHV-1 Infection

Viral DNA amount in hemolymph from adult oysters incubated with viral suspension was determined at each post-incubation time $(2 \mathrm{~h}, 4 \mathrm{~h}, 6 \mathrm{~h}$, or $18 \mathrm{~h})$ and was then compared to viral DNA amount in hemolymph at $0 \mathrm{~h}$ post-incubation time (T0): $\mathrm{R}$ ratio (Figure 2). Precisely, the sample time T0 corresponds to the contact period between hemolymph and viral suspension during the centrifugation step that occurred just before the DNA extraction step. The higher the $\mathrm{R}$ ratio was, the higher the viral DNA amount was in the hemolymph. At $18 \mathrm{~h}$ post-incubation, the amount of OsHV-1 DNA was significantly higher in hemolymph from adult oysters presenting a high susceptibility to OsHV1 infection (oysters from families A, B, C, and E) than those collected from adult oysters which are less susceptible to OsHV-1 infection (oysters from families $\mathrm{D}$ and $\mathrm{F}$; $p<0.01$ ) (Figure 2).

\section{Number of Viral Transcripts in Hemolymph From Adult Oysters With Different Susceptibility to Oyster Infection at $18 \mathrm{~h}$ Post-incubation}

As the highest OsHV-1 DNA detection in hemolymph incubated with viral suspension was reported at $18 \mathrm{~h}$ post-incubation, this sample time was selected to evaluate the number of viral transcripts in the same in vitro conditions. The number of three viral transcripts (ORF 72, ORF 75, and ORF 87) was reported for hemolymph collected from adult oysters presenting different susceptibility to OsHV-1 infection, incubated with viral suspension (Figure 3). The mean transcript amount of the three targeted ORF at $18 \mathrm{~h}$ post-incubation was 2.95 -fold higher than that at $0 \mathrm{~h}$ post-incubation, whatever the oyster susceptibility to OsHV-1 infection $(p<0.0001)$ (Figure 3). At
$0 \mathrm{~h}$ post-incubation (T0) with viral suspension, no significant difference was observed between hemolymph collected from adult oysters presenting a high susceptibility to OsHV-1 infection ( $\mathrm{C}$ and $\mathrm{E}$ oyster families) and those collected from adult oysters which are less susceptible to OsHV-1 infection (D and F oyster families; $p>0.05$ ) (Figure 3 ). In contrast to $18 \mathrm{~h}$ postincubation with viral suspension, ORF 87 transcript amount was significantly higher in hemolymph collected from adult oysters presenting a high susceptibility to OsHV-1 infection (oysters from families $\mathrm{C}$ and $\mathrm{E}$ ) in comparison to viral transcript number in hemolymph collected from adult oysters which are less susceptibility to OsHV-1 infection (oysters from families D and F; $p<0.05$ ) (Figure 3).

\section{Effect of Antiviral Antibodies on OsHV-1 Infection in in vitro Condition}

Comparison of OsHV-1 DNA Amounts in Hemolymph Incubated With OsHV-1 Suspension Versus Hemolymph Incubated With OsHV-1 Suspension Containing Antiviral Antibodies

Viral DNA amount in hemolymph from adult oysters was determined at each time post-incubation $(2 \mathrm{~h}, 4 \mathrm{~h}$, and $6 \mathrm{~h}$ ) for each condition: hemolymph incubated with viral suspension versus hemolymph incubated with viral suspension in presence of the three polyclonal antibodies. No significant difference of viral DNA copies per $\mu \mathrm{L}$ of DNA extract was observed between adult oyster hemolymph incubated with viral suspension $(\log 5.65 \pm 0.06, \log 5.62 \pm 0.13$, and $\log 5.89 \pm 0.14)$ and viral suspension containing antiviral antibodies $(\log 5.68 \pm 0.02, \log 5.84 \pm 0.11$, and $\log$ $5.71 \pm 0.09$ ) at $1 \mathrm{~h}, 4 \mathrm{~h}$, and $6 \mathrm{~h}$ post-incubation (the three $p$-values were superior to 0.05 for each post-incubation time). Viral DNA amounts obtained for adult hemolymph incubated with viral suspension containing anti-GFP antibodies were similar to those reported with hemolymph incubated with viral suspension at $6 \mathrm{~h}$ post-incubation (data not shown).

Secondly, a similar experiment was conducted by incubating viral suspension with polyclonal antibodies separately (Table 2) at $19^{\circ} \mathrm{C}$ for $6 \mathrm{~h}$. Viral DNA amount was significantly lower in hemolymph incubated with viral suspension containing anti-ORF 25 antibodies $(p=0.011)$ or anti-ORF 41 antibodies $(p=0.013)$ in comparison with hemolymph incubated with viral suspension (Table 2). No significant difference of viral DNA amount was observed between hemolymph incubated with viral suspension containing anti-ORF $72(p=0.331)$ or anti-GFP $(p=0.619)$ antibodies and hemolymph incubated with viral suspension (Table 2).

Number of Viral Transcripts in Hemolymph From Adult Oysters Incubated With OsHV-1 Suspension Versus Hemolymph Incubated With OsHV-1 Suspension Containing Antiviral Antibodies

At $4 \mathrm{~h}$ and $6 \mathrm{~h}$ post-incubation, the number of viral transcripts was significantly higher in hemolymph incubated with viral 

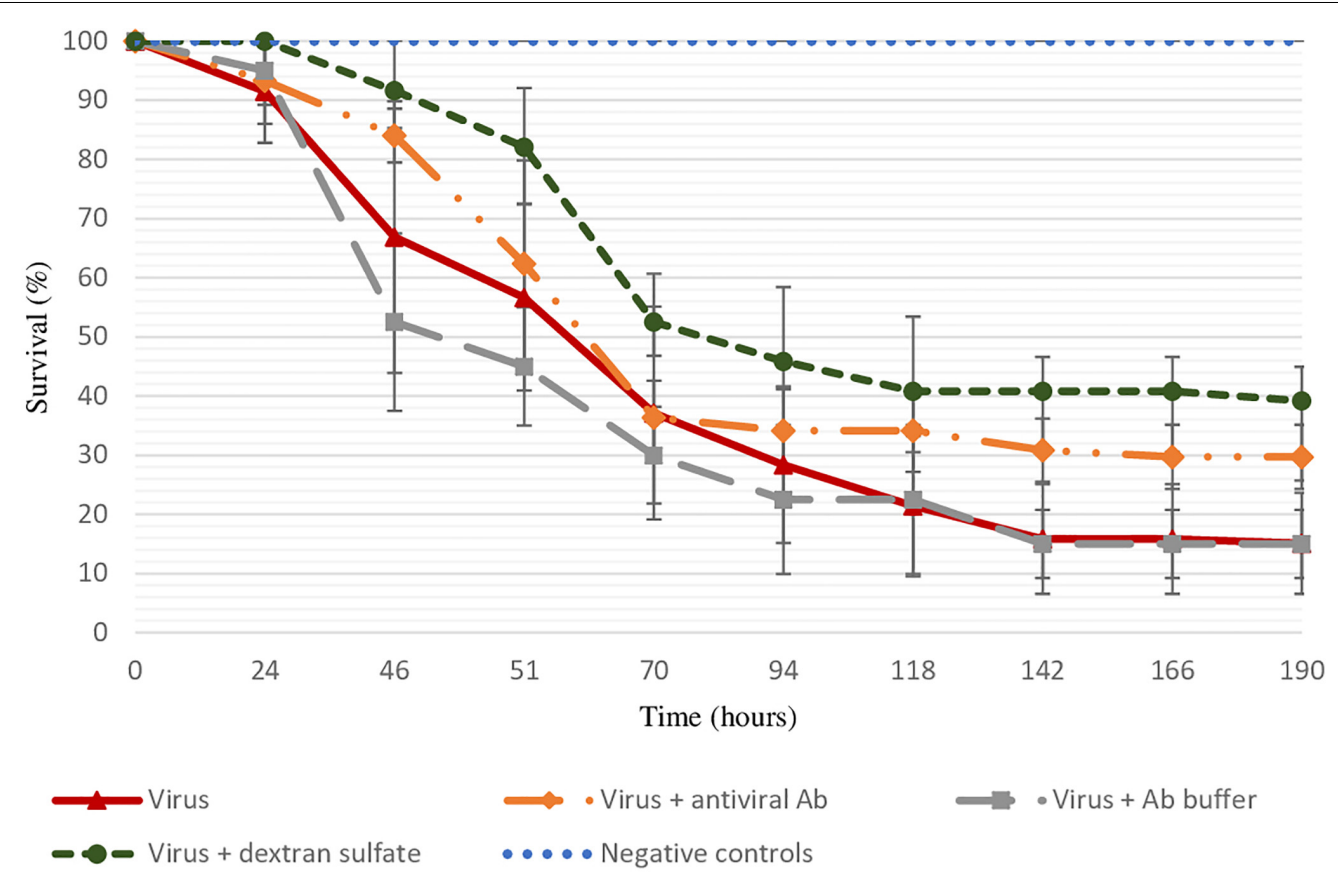

- Virus + Ab buffer

FIGURE 1 | Survival rate of spat injected with viral suspension, viral suspension incubated with the three antiviral antibodies or with dextran sulfate (30 $\mu \mathrm{g} / \mathrm{mL})$, and negative controls (sterilized ASW, "control suspension" incubated with antibody buffer, "control suspension" incubated with dextran sulfate at $30 \mu \mathrm{g} / \mathrm{mL}$ ) during 8 days. Error bars represent standard deviation of produced data.

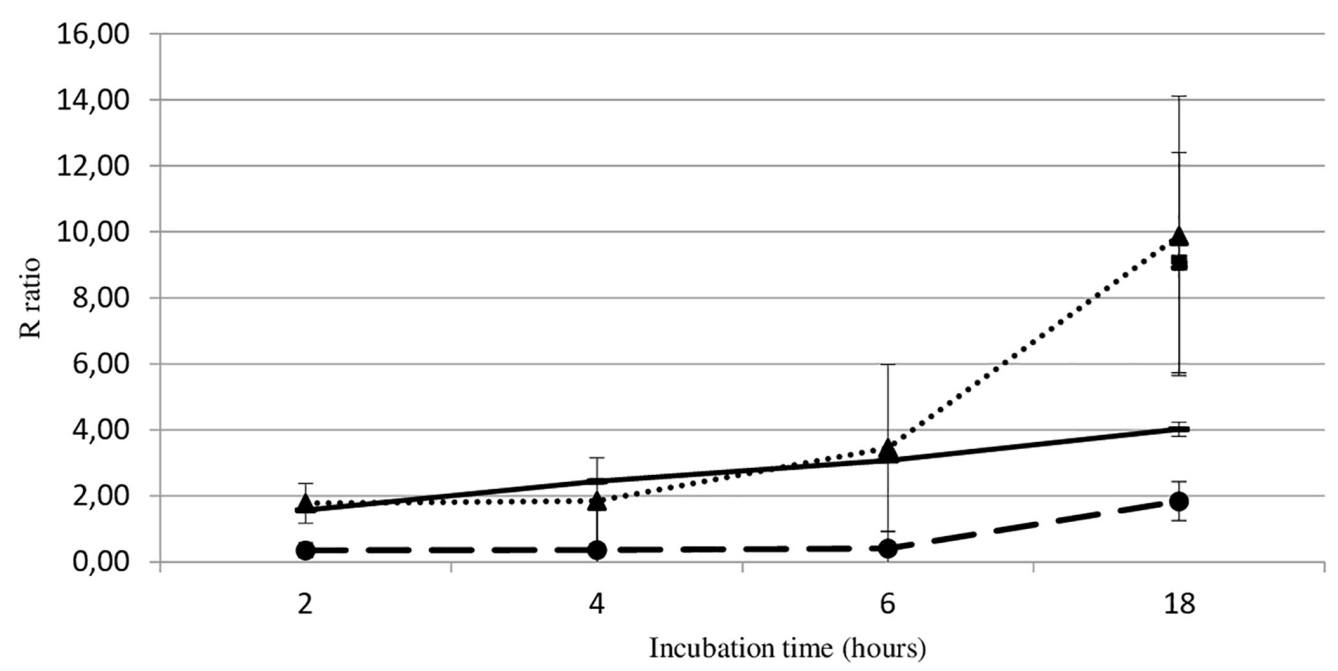

$\cdots$... A,B, C families $\longrightarrow$ E family $\longrightarrow$ - F family

FIGURE 2 | OsHV-1 DNA amount trend in haemocytes from different oyster families incubated with viral suspension through time (hours). The R ratio corresponds to the viral DNA amount at each time post-incubation in comparison with the viral DNA amount at $\mathrm{O}$ h post-incubation (TO) in haemolymph. Error bars represent standard deviation of produced data.

suspension in comparison with hemolymph incubated with OsHV-1 suspension containing the three antiviral antibodies ( $p$ values ranged from 0.002 to 0.014 for each of the three targeted ORFs and for both incubation periods) (Figure 4). No significant difference was reported between ORF75 transcript amounts in hemolymph incubated with OsHV-1 suspension and those incubated with viral suspension containing anti-GFP antibodies at $6 \mathrm{~h}$ post-incubation $(p=0.370)$ (Figure 4). There were significantly less ORF $72(p=0.016)$, ORF $75(p=0.006)$, and ORF $87(p=0.024)$ transcripts in hemolymph incubated with OsHV-1 suspension in the presence of antiviral antibodies than those incubated with 


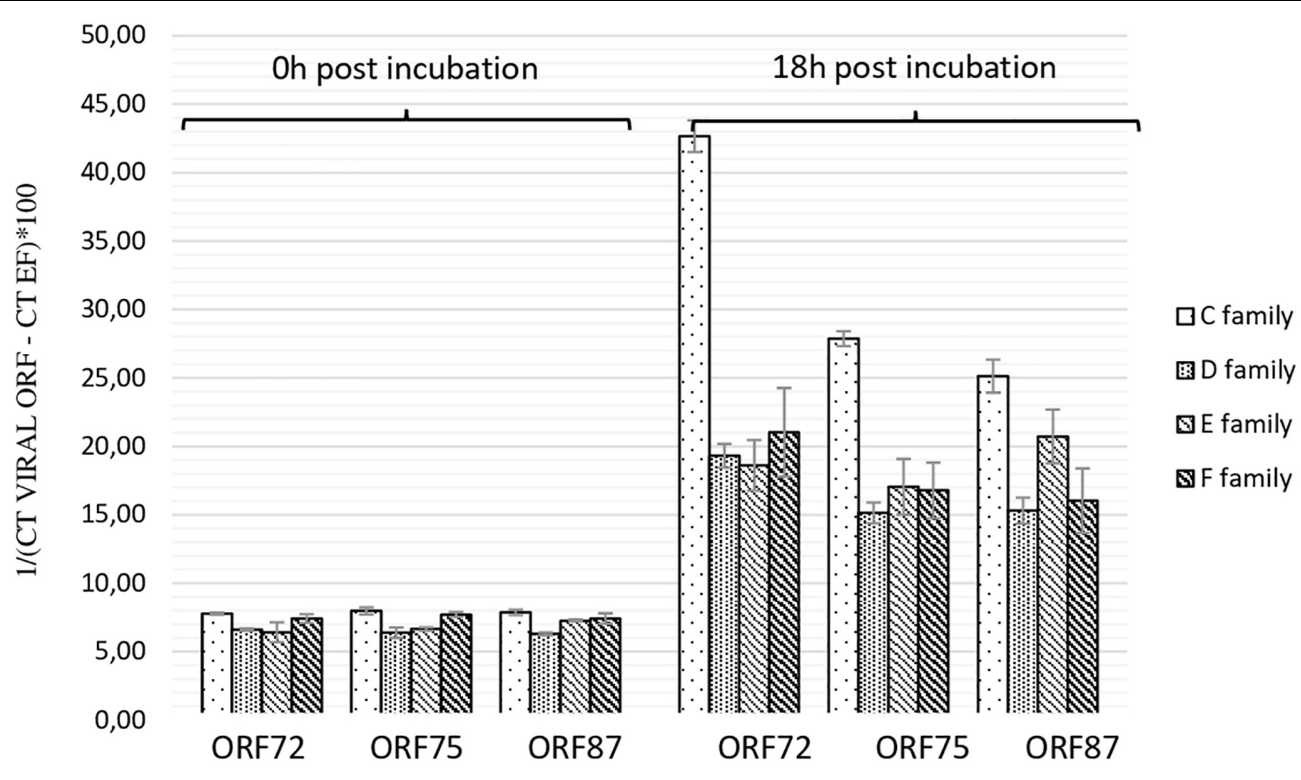

FIGURE 3 | Number of viral transcripts in haemolymph from adult oysters presenting different susceptibility to oyster infection at $0 \mathrm{~h}$ and $18 \mathrm{~h}$ post-incubation for ORF 72, ORF 75, and ORF 87. Error bars represent standard deviation of produced data.

viral suspension containing anti-GFP antibodies at $6 \mathrm{~h}$ post-incubation (Figure 4).

Secondly, a similar experiment was conducted by incubating viral suspension with polyclonal antibodies separately at $19^{\circ} \mathrm{C}$ for $6 \mathrm{~h}$ (Figure 5). Viral transcript amount was significantly lower in hemolymph incubated with viral suspension containing antiORF25, anti-ORF41 or anti-ORF72 antibodies in comparison with those incubated with viral suspension alone ( $p$ values were inferior to 0.016 for the three tested conditions and for each of the three targeted ORF, excepted for ORF 75 transcripts in the condition with viral suspension containing anti-ORF41 compared to viral suspension alone) (Figure 5). No significant difference was reported between ORF75 transcript amounts in hemolymph incubated with OsHV-1 suspension and those incubated with viral suspension containing anti-GFP antibodies at $6 \mathrm{~h}$ post-incubation $(p=0.076)$ (Figure 5). There were significantly less ORF 72, ORF 75, and ORF 87 transcripts in hemolymph incubated with OsHV-1 suspension in presence of anti-ORF25, anti-ORF41 or anti-ORF72 antibodies than those incubated with viral suspension containing anti-GFP antibodies

TABLE 2 | Number of viral DNA copies per $\mu L$ of DNA extract (log10) in adult oyster haemolymph incubated with the viral suspension or with the viral suspension containing antiviral (anti-ORF 25, or anti-ORF 41, or anti-ORF 72) or anti-GFP antibodies at $6 \mathrm{~h}$ post-incubation (* for $p<0.05)$.

\begin{tabular}{lccc}
\hline Conditions & TOh & T6 $\mathbf{h}$ & $\mathbf{A}=\mathbf{~ T 6 ~} \mathbf{h}-\mathbf{T 0} \mathbf{~}$ \\
\hline Virus & 4.48 & 4.92 & 0.44 \\
Virus + anti-ORF 25 & $4.51 \pm 0.02$ & $4.71 \pm 0.01$ & $0.20^{*}$ \\
Virus + anti-ORF 41 & $4.53 \pm 0.04$ & $4.67 \pm 0.05$ & $0.14^{*}$ \\
Virus + anti-ORF 72 & $4.36 \pm 0.03$ & $4.76 \pm 0.02$ & 0.40 \\
Virus + anti-GFP & $4.39 \pm 0.12$ & $4.86 \pm 0.07$ & 0.47
\end{tabular}

at $6 \mathrm{~h}$ post-incubation ( $p$ values were lower than 0.028 for the three tested conditions and for each of the three targeted ORFs, with the exception of ORF 75 and ORF 87 transcripts in the condition with viral suspension containing anti-ORF41 compared to viral suspension containing anti-GFP antibodies) (Figure 5). No viral RNA was detected under the control condition (hemolymph alone).

\section{Effect of Dextran Sulfate on OsHV-1 Infection in in vitro Condition} Comparison of OsHV-1 DNA Amounts in Hemolymph Incubated With OsHV-1 Suspension Versus Hemolymph Incubated With OsHV-1 Suspension Containing Dextran Sulfate at $6 \mathrm{~h}$ Post-incubation

Viral DNA amount was significantly lower in hemolymph incubated with viral suspension containing dextran sulfate at $30 \mu \mathrm{g} / \mathrm{mL}(p=0.016)$ or at $300 \mu \mathrm{g} / \mathrm{mL}(p=0.007)$ in comparison with those incubated with viral suspension alone (Table 3 ).

\section{Number of Viral Transcripts in Hemolymph From Adult Oysters Incubated With OsHV-1 Suspension Versus Hemolymph Incubated With OsHV-1 Suspension Containing Dextran Sulfate at $6 \mathrm{~h}$ Post-incubation}

At $6 \mathrm{~h}$ post-incubation, the amount of viral transcripts was significantly higher in hemolymph incubated with viral suspension containing dextran sulfate at $30 \mu \mathrm{g} / \mathrm{mL}$ ( $p$ values were inferior to 0.011 for each of the three targeted ORF) or $300 \mu \mathrm{g} / \mathrm{mL}$ ( $p$ values were inferior to 0.024 for each of the three targeted ORF) in comparison with those incubated with viral suspension alone (Figure 6). The number of viral transcripts was significantly lower in hemolymph incubated with 


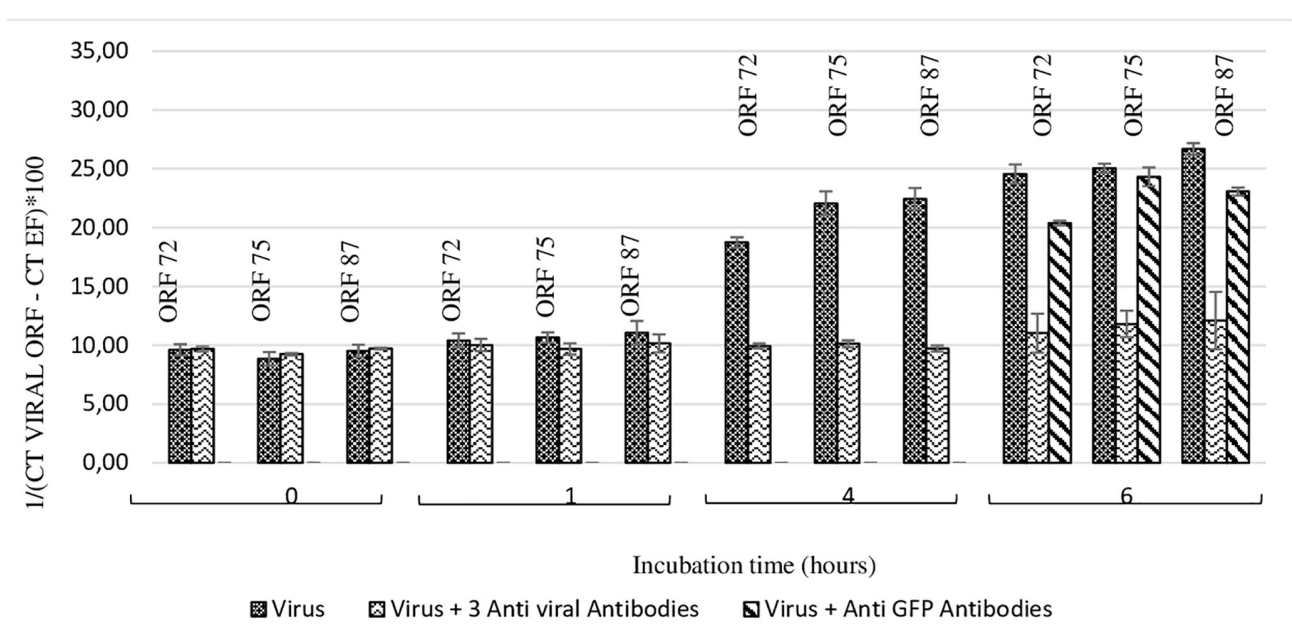

FIGURE 4 | Number of viral transcripts in haemolymph from adult oysters incubated with the viral suspension or the viral suspension containing the three anti-viral or anti-GFP antibodies at $0 \mathrm{~h}, \mathrm{I}$ h, $4 \mathrm{~h}$, or $6 \mathrm{~h}$ post-incubation for ORF 72, ORF 75, and ORF 87. Error bars represent standard deviation of produced data.

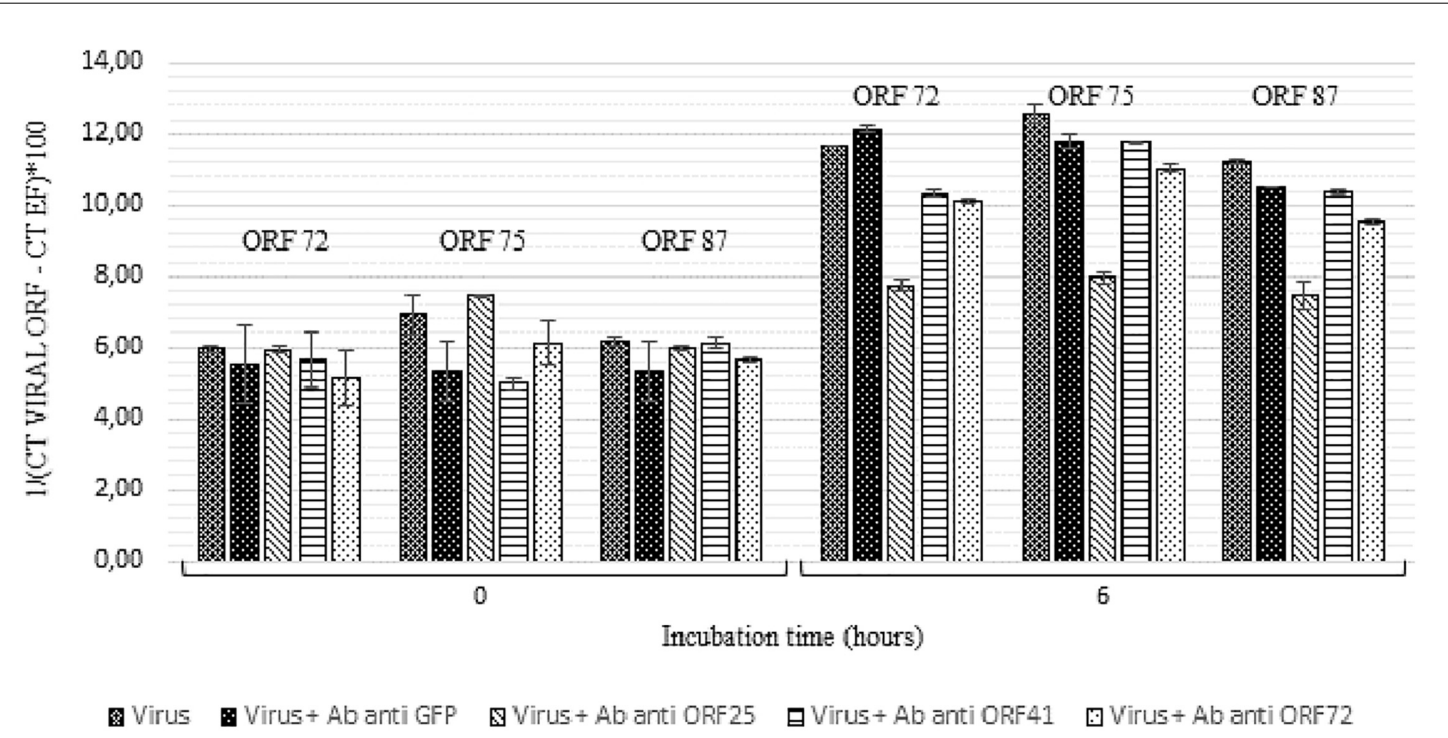

FIGURE 5 | Number of viral transcripts in haemolymph from adult oysters incubated with the viral suspension or the viral suspension containing anti-viral or anti-GFP antibodies separately at $\mathrm{O}$ h and $6 \mathrm{~h}$ post-incubation for ORF 72, ORF 75, and ORF 87. Error bars represent standard deviation of produced data.

viral suspension containing dextran sulfate at $30 \mu \mathrm{g} / \mathrm{mL}$ than in those incubated with viral suspension containing dextran sulfate at $300 \mu \mathrm{g} / \mathrm{mL}$ at $6 \mathrm{~h}$ post-incubation ( $p$ values were inferior to 0.031 for each of the three targeted ORFs, except for ORF 72 transcripts) (Figure 6). No viral RNA was detected under the control condition (hemolymph alone).

\section{DISCUSSION}

The infection process of herpesviruses begins with virus attachment to cells by numerous molecular bindings, followed by fusion of virion envelope with cell membrane, allowing viral capsid penetration in host cells. Viral entry mechanisms of herpesviruses constitutes a highly complex process which implicates several viral proteins and glycoproteins present in the virion lipid bilayer and different cellular receptors located on host cell surfaces (Spear and Longnecker, 2003; Spear, 2004; Agelidis and Shukla, 2015).

To identify which OsHV-1 glycoproteins might be implicated in attachment of the virus to oyster cells, three viral proteins were first selected and polyclonal antibodies against these targets were used to try to inhibit interactions with cellular receptors, restricting entry of OsHV-1 into host cells. The selection of OsHV-1 putative membrane proteins was based on protein sequence homology and results obtained from transcriptomic 
TABLE 3 | Number of viral DNA copies per $\mu L$ of DNA extract (log10) in adult oyster haemolymph incubated with the viral suspension or viral suspension containing dextran sulfate at $30 \mu \mathrm{g} / \mathrm{mL}$ or $300 \mu \mathrm{g} / \mathrm{mL}$ at $0 \mathrm{~h}$ and $6 \mathrm{~h}$ post-incubation (* for $p<0.05)$.

\begin{tabular}{lccc}
\hline Conditions & TOh & T6 $\mathbf{~}$ & $\mathbf{A}=\mathbf{~ T 6 ~} \mathbf{~}-\mathbf{T}$ 0 $\mathbf{~}$ \\
\hline Virus & 3.47 & 3.96 & 0.46 \\
$\begin{array}{l}\text { Virus }+ \text { Dextran sulfate } \\
(30 \mu \mathrm{g} / \mathrm{mL})\end{array}$ & $4.10 \pm 0.02$ & $4.15 \pm 0.09$ & $0.05^{*}$ \\
$\begin{array}{l}\text { Virus }+ \text { Dextran sulfate } \\
(300 \mu \mathrm{g} / \mathrm{mL})\end{array}$ & $4.35 \pm 0.34$ & $4.18 \pm 0.15$ & $-0.17^{*}$ \\
\hline
\end{tabular}

and gene expression approaches during OsHV-1 experimental infection, which were conducted to better understand the OsHV1 infection cycle (Davison et al., 2005; Jouaux et al., 2013; Rosani et al., 2014; Segarra et al., 2014b). Three proteins encoded by ORF 25, ORF 41, and ORF 72 appeared to be suitable candidates for the present investigation, since these proteins might correspond to proteins located on the viral envelope surface, and therefore play a key role in interactions between virus and host. However, they do not share homology with already known membrane glycoproteins from other herpesviruses as all other OsHV-1 putative membrane proteins.

Results from experimental trials showed a significant lower mortality rate of spat injected with viral suspension incubated in presence of the three antiviral antibodies in comparison with spat injected with viral suspension alone (70 and $85 \%$, respectively). These results must be considered in these controlled conditions, antiviral antibody concentrations, and genetic background of oysters. The mortality rate recorded during in vivo trials was associated with OsHV-1 infection, since higher viral DNA amounts were detected in dead oysters, which were in accordance with those previously reported (Oden et al., 2011; Schikorski et al., 2011a,b). The impact of chemical composition of antibody buffer was controlled by injecting buffer solution in the adductor muscle of spat and no mortality was recorded. The specific effect of antiviral antibodies was investigated by injecting into the spat adductor muscle a viral suspension incubated with anti-GFP antibodies. As no significant difference of mortality rate was reported between oysters injected with viral suspension incubated with anti-GFP antibodies and viral suspension alone, the results suggest that the observed effect in the presence of the three antiviral antibodies was specific to the target of antiviral antibodies. Even if this experimental approach presents the advantage of injecting the same concentration of viral suspension and antibodies into each oyster, injection into the adductor muscle did not constitute the natural way for OsHV1 infection and could explain the low difference of mortality rates between oysters injected with viral suspension incubated with antiviral antibodies and those injected with the viral suspension alone. No information is available on antibody stability after they have been injected into oysters either. Other experimental approaches, consisting of putting uninfected oysters into contact with experimentally infected ones, were not chosen for the present study since the required antibody amounts were too high. In this context in vitro approaches were implemented from a protocol developed by Morga et al. (2017) using spat hemolymph to better control ligand/cellular receptor interactions and to limit dilution effects that occurred in in vivo trials. This protocol was firstly adapted to hemolymph collected from adult oysters to sample larger amounts of circulating cells. Previous works reported OsHV-1 DNA, RNA, and protein detection in adult oysters, suggesting that OsHV-1 might enter in adult hemolymph/hemocytes (Arzul et al., 2002; Barbosa-Solomieu et al., 2005; Segarra et al., 2014a; Azéma et al., 2016). Additionally, oysters selected for their higher susceptibility to OsHV-1 show high mortality related to OsHV-1 infection at all life stages, including the adult stage (Azéma et al., 2017).

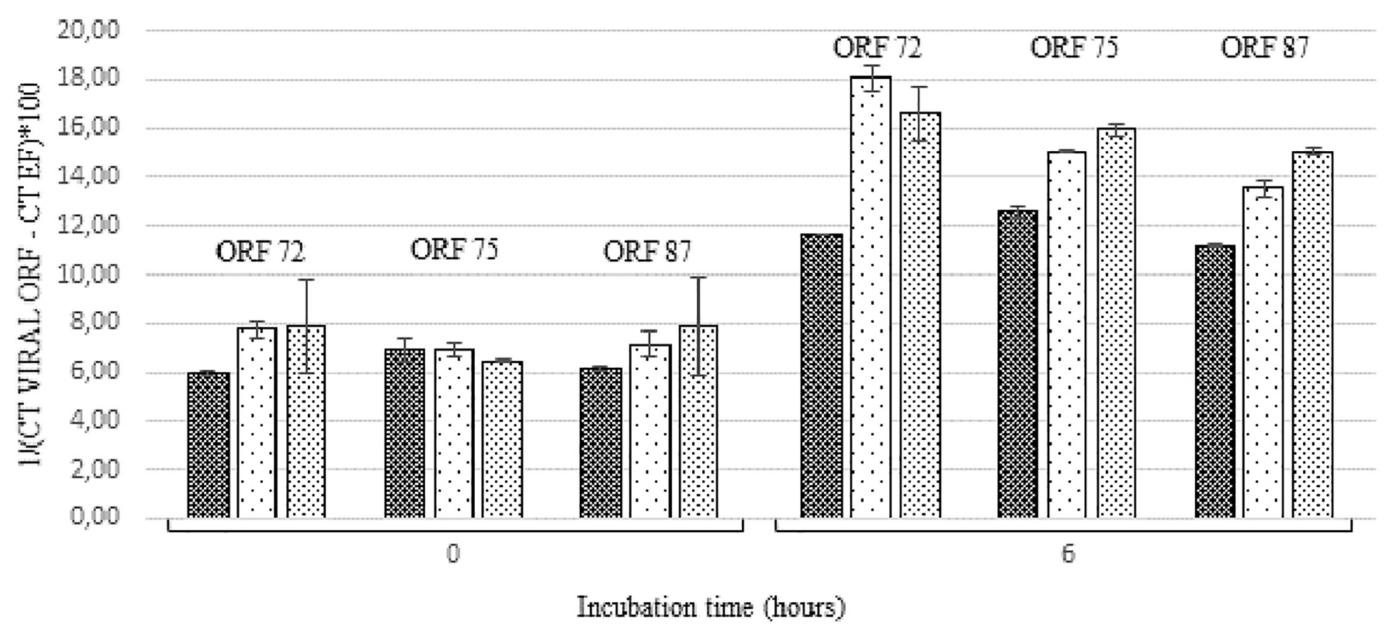

QVirus $\quad$ QVirus+dextransulfate $(30 \mu g / \mathrm{mL}) \quad$ Q Virus + dextran su fate $(300 \mu g / \mathrm{mL})$

FIGURE 6 | Number of viral transcripts in haemolymph from adult oysters incubated with the viral suspension or the viral suspension containing dextran sulfate at $30 \mu \mathrm{g} / \mathrm{mL}$ or $300 \mu \mathrm{g} / \mathrm{mL}$ at $\mathrm{O}$ h and $6 \mathrm{~h}$ post-incubation for ORF 72, ORF 75, and ORF 87. Error bars represent standard deviation of produced data. 
OsHV-1 RNA and DNA detection in adult hemolymph incubated with OsHV-1 suspension showed that OsHV-1 has the ability to recognize cellular receptors located on hemocyte's surface and to enter in these immune cells, regardless of the hemolymph origin (spat or adult oyster) and susceptibility of oysters to OsHV1 infection (Figure 3). This contrast with the absence of viral RNA detection $144 \mathrm{~h}$ post-injection into the adductor muscle of adult oysters suggests that adult oysters might be able to control viral replication (Segarra et al., 2014a). A significant higher number of viral transcripts in adult oysters showing high susceptibility to OsHV-1 infection at $18 \mathrm{~h}$ post-incubation is in agreement with a genetic basis of resistance to viral infection as previously reported (Dégremont et al., 2015; Azéma et al., 2017). The present results are also in accordance with those obtained by Segarra et al. (2014b), who investigated OsHV-1 infection in spat presenting high and low susceptibility level to OsHV-1 infection and reported a significant difference of OsHV1 DNA and RNA amounts between different oyster families in association with dissimilar host gene expression profiles. In light of these results, hemolymph from adult oysters presenting a high susceptibility to OsHV-1 infection was selected to test for the antiviral antibody effect on OsHV-1 in in vitro conditions. At $6 \mathrm{~h}$ post-incubation, a significant difference in the number of viral transcripts was observed in hemolymph incubated with viral suspension containing three viral antibodies or antiviral antibodies targeting proteins encoded by ORF 25 , ORF 41, and ORF 72 in comparison with hemolymph incubated with viral suspension alone (Table 4). These results lead to the assumption that the three targeted viral proteins, and mainly protein encoded by ORF 25 , might be implicated in virus attachment to oyster cells. However, the detection of viral DNA or RNA in hemolymph incubated with the viral suspension incubated with antiviral antibodies (either separately or in mixture) suggested that other OsHV-1 proteins were required to allow virus attachment to cellular receptors or/and that antiviral antibody concentrations were not sufficient to completely inhibit interactions between ligands and cellular receptors. It is highly probable that other OsHV-1 proteins are implicated in this stage since the attachment of herpes simplex virus 1 (HSV-1) and herpes simplex virus 2 (HSV-2) required at least four viral envelop glycoproteins (gB, $\mathrm{gD}, \mathrm{gH}$, and $\mathrm{gL}$ ), which are absolutely essential for HSV-1 and

TABLE 4 | Trends of viral DNA and RNA detection in adult oyster haemolymph incubated with OsHV-1 suspension in presence of anti-viral (anti-ORF25, anti-ORF41, and anti-ORF72; separately or in mixture).

\begin{tabular}{lcccc}
\hline $\begin{array}{c}\text { Three antiviral } \\
\text { antibodies }\end{array}$ & $\begin{array}{c}\text { Anti- } \\
\text { ORF25 }\end{array}$ & $\begin{array}{c}\text { Anti- } \\
\text { ORF41 }\end{array}$ & $\begin{array}{c}\text { Anti- } \\
\text { ORF72 }\end{array}$ \\
\hline OsHV-1 DNA & - & $\searrow$ & $\searrow$ & - \\
ORF 72 transcripts & $\searrow$ & $\searrow$ & $\searrow$ & $\searrow$ \\
ORF 75 transcripts & $\searrow$ & $\searrow$ & - & $\searrow$ \\
ORF 87 transcripts & $\searrow$ & $\searrow$ & $\searrow$ & $\searrow$ \\
\hline
\end{tabular}

Arrows correspond to significant decrease of OsHV-1 DNA amount or viral transcript number in haemolymph incubated with the viral suspension in presence of antibodies in comparison with those incubated with the viral suspension alone. A dash was indicated no significant difference between the two incubation conditions (viral suspension incubated in presence or without antibodies).
HSV-2 entry into host cells (Agelidis and Shukla, 2015). Some of them bind to cellular receptors, increasing virion number around cells, whereas other glycoproteins recognize specifically cellular receptors for membrane fusion allowing virions to enter cells (Spear and Longnecker, 2003). Further investigations need to be conducted to better characterize molecular interactions at the ligand/receptor level and identify other viral glycoproteins which are implicated in virus attachment to oyster cells. In addition, molecular interactions between OsHV-1 proteins and antiviral antibodies can be reversible (no destructive effect) and might be unstable in the experimental conditions tested. Consequently, OsHV-1 can finally achieve entry into host cells and begin its replication cycle until induced spat death in in vivo trials. Different effects observed between three antiviral antibodies against ORF 25, ORF 41, and ORF 72 proteins could be due to their specific role in virus attachment to cells or the number of these proteins on the OsHV-1 surface.

Herpes simplex virus adsorption to host cells is mediated by several cellular molecules, which act as cofactors, including herpesvirus entry mediator (HVEM), nectin-1, and glycosaminoglycans (Whitbeck et al., 1997; Connolly et al., 2001; Tiwari et al., 2006; Farooq et al., 2010; Karasneh and Shukla, 2011). Among glycosaminoglycans, heparan sulfate proteoglycans (HSPG) and chondroitin sulfate, which are present on the cell surface, were reported to be involved in the step of viral entry (Dyer et al., 1997; Spear and Longnecker, 2003; Agelidis and Shukla, 2015). Dextran sulfate, a negatively charged sulfated polysaccharide, was used as a glycosaminoglycan analog, and two concentrations of this molecule were tested in the present study to explore the nature of virus/host interactions (Dyer et al., 1997). Mortality was significantly lower for oysters injected with dextran sulfate added in viral suspension in comparison with those injected with viral suspension alone (60 and 85\%, respectively). In vitro trials revealed that OsHV-1 DNA amounts in hemolymph incubated with viral suspension in the presence of dextran sulfate were significantly lower than those detected in hemolymph incubated with viral suspension alone. On the contrary, the number of viral transcripts was higher in hemolymph incubated with OsHV-1 suspension in the presence of dextran sulfate than in hemolymph incubated with viral suspension alone. Taken together, these results suggest that dextran sulfate might play an antiherpetic effect (decrease of final mortality rates and viral DNA production in in vitro trials) but does not affect viral transcription. A hypothetic effect of dextran sulfate on OsHV-1 capsid integrity was not demonstrated in the present study and does not account for decrease of final mortality rates or viral DNA production in in vitro trials. The effect of dextran sulfate differs in respect with studied viruses even if dextran sulfate is mainly known to inhibit viral attachment to target cells (Vaheri, 2007). However, Dyer et al. (1997) reported that dextran sulfate added either prior to or during inoculation stimulated herpes simplex virus 1 (HSV-1) but not herpes simplex virus 2 (HSV-2) infection and occurred during an early, energy-independent step in infection. Glycosaminoglycans in HSV infection constitute an efficient matrix for virus adsorption. On the contrary Huemer et al. (1992) showed that dextran sulfate inhibited binding of HSV glycoprotein C to complement third 
component ( $\mathrm{C} 3 \mathrm{~b})$. Inhibition effects change in respect to dextran sulfate concentration and molecular weight dextran sulfate (Huemer et al., 1992). In addition, in vitro experiments revealed that dextran sulfate significantly reduced the number of lytic plaques caused by pseudorabies virus (Suid herpesvirus 1), but did not modify the virulence of this virus in mice (Ramos-Kuri et al., 1990). A similar trend of the dextran sulfate effect was reported for influenza A virus strain at the initial and late stages of the viral infection process, which might suppress its replication (Yamada et al., 2012, 2014). More precisely, dextran sulfate is associated with inhibition of hemagglutinin-dependent fusion activity (initial stage of viral infection process) and may also be involved in inhibition of neuraminidase activity by dextran sulfate negative charge (later stage of viral infection) (Yamada et al., 2012, 2014). The potential inhibitor effect of dextran sulfate on Sendai virus fusion and erythrocyte ghosts was also described where dextran sulfate likely interacted preferentially with Sendai virion surfaces (Ohki et al., 1991). Supplementary investigation was required to reinforce these results by studying a dosedependent effect of dextran sulfate. In addition, the antiherpetic effect of other polyanions such as heparin and chondroitin sulfate could be tested to complete the present results.

\section{CONCLUSION}

Results obtained from assays conducted on hemolymph from adult oysters presenting different levels of susceptibility to OsHV1 infection revealed that the virus is able to enter immune cells, product DNA and RNA regardless of the stage of oyster development or the genetic background.

Original and nondestructive approaches were applied in the present study to identify OsHV-1 proteins which might be implicated in virus attachment on host cells. This is the first time

\section{REFERENCES}

Abbadi, M., Zamperin, G., Gastaldelli, M., Pascoli, F., Rosani, U., Milani, A., et al. (2018). Identification of a newly described OsHV-1 $\mu$ var from the North Adriatic Sea (Italy). J. Gen. Virol. 99, 693-703. doi: 10.1099/jgv.0.001042

Agelidis, A. M., and Shukla, D. (2015). Cell entry mechanisms of HSV: what we have learned in recent years. Future Virol. 10, 1145-1154. doi: 10.2217/fvl.15.85

Aranguren, R., Costa, M., Novoa, B., and Figueras, F. (2012). Detection of herpesvirus variant (OsHV-1 mu var) in Pacific oysters (Crassostrea gigas) in Spain and development of a rapid method for its differential diagnosis. Bull. Eur. Ass. Fish Pathol. 32, 24-29.

Arzul, I., Renault, T., Thébault, A., and Gérard, A. (2002). Detection of oyster herpesvirus DNA and proteins in asymptomatic Crassostrea gigas adults. Virus Res. 84, 151-160. doi: 10.1016/S0168-1702(02)00007-2

Azéma, P., Lamy, J.-B., Boudry, P., Renault, T., Travers, M.-A., and Dégremont, L. (2017). Genetic parameters of resistance to Vibrio aestuarianus, and OsHV-1 infections in the Pacific oyster, Crassostrea gigas, at three different life stages. Genet. Sel. Evol. GSE 49:23. doi: 10.1186/s12711-017-0297-2

Azéma, P., Travers, M.-A., Benabdelmouna, A., and Dégremont, L. (2016). Single or dual experimental infections with Vibrio aestuarianus and OsHV-1 in diploid and triploid Crassostrea gigas at the spat, juvenile and adult stages. J. Invertebr. Pathol. 139, 92-101. doi: 10.1016/j.jip.2016.08.002

Baba, M., Pauwels, R., Balzarini, J., Arnout, J., Desmyter, J., and De Clercq, E. (1988). Mechanism of inhibitory effect of dextran sulfate and heparin on that one OsHV-1 putative viral envelop protein encoded by ORF 25 is suggested to be a potential candidate for involvement in the initial stage of the viral infection process and subsequently these results contribute to a better understanding of viral infection pathogenesis.

The antiherpetic effect of dextran sulfate was investigated against OsHV-1 infection and revealed an interesting approach to limit viral infection in controlled conditions such as oyster hatcheries or nurseries, and it therefore needs to be explored and tested more in combination with other polysaccharides.

\section{DATA AVAILABILITY}

The raw data supporting the conclusions of this manuscript will be made available by the authors, without undue reservation, to any qualified researcher.

\section{AUTHOR CONTRIBUTIONS}

CM and TR conceived the experimentations. CM and NF realized the experimentations. LD provided the oysters. J-BL realized a part of the statistical analysis. CM and TR wrote the first draft of the manuscript. All authors reviewed the manuscript and approved the final version to be submitted for publication.

\section{FUNDING}

This work received financial support from the European projects "MOLecular TRacing of viral pathogens in AQuaculture" (MOLTRAQ) and "Improving European mollusk aquaculture: disease detection and management” (Bivalife).

replication of human immunodeficiency virus in vitro. Proc. Natl. Acad. Sci. U.S.A. 85, 6132-6136. doi: 10.1073/pnas.85.16.6132

Bagasra, O., and Lischner, H. W. (1988). Activity of dextran sulfate and other polyanionic polysaccharides against human immunodeficiency virus. J. Infect. Dis. 158, 1084-1087. doi: 10.1093/infdis/158.5.1084

Bai, C.-M., Morga, B., Rosani, U., Shi, J., Li, C., Xin, L.-S., et al. (2019). Longrange PCR and high-throughput sequencing of Ostreid herpesvirus 1 indicate high genetic diversity and complex evolution process. Virology 526, 81-90. doi: 10.1016/j.virol.2018.09.026

Bai, C.-M., Wang, Q.-C., Morga, B., Shi, J., and Wang, C.-M. (2017). Experimental infection of adult Scapharca broughtonii with Ostreid herpesvirus SB strain. J. Invertebr. Pathol. 143, 79-82. doi: 10.1016/j.jip.2016.12.001

Barbosa-Solomieu, V., Dégremont, L., Vázquez-Juárez, R., Ascencio-Valle, F., Boudry, P., and Renault, T. (2005). Ostreid herpesvirus 1 (OsHV-1) detection among three successive generations of Pacific oysters (Crassostrea gigas). Virus Res. 107, 47-56. doi: 10.1016/j.virusres.2004.06.012

Batista, F. M., López-Sanmartín, M., Boudry, P., Navas, J. I., Ruano, F., Renault, T., et al. (2014). Insights on the association between somatic aneuploidy and ostreid herpesvirus 1 detection in the oysters Crassostrea gigas, C. angulata and their F1 hybrids. Aquac. Res. 5, 1530-1536. doi: 10.1111/are. 12613

Bingham, P., Brangenberg, N., Williams, R., and van Andel, M. (2013). Investigation into the first diagnosis of ostreid herpesvirus type 1 in Pacific oysters. Surveillance 40, 20-24. 
Bolker, B. M., Brooks, M. E., Clark, C. J., Geange, S. W., Poulsen, J. R., Stevens, M. H. H., et al. (2009). Generalized linear mixed models: a practical guide for ecology and evolution. Trends Ecol. Evol. 24, 127-135. doi: 10.1016/j.tree.2008. 10.008

Burge, C. A., Griffin, F. J., and Friedman, C. S. (2006). Mortality and herpesvirus infections of the Pacific oyster Crassostrea gigas in Tomales Bay, California, USA. Dis. Aquat. Organ. 72, 31-43. doi: 10.3354/dao072031

Burge, C. A., Strenge, R. E., and Friedman, C. S. (2011). Detection of the oyster herpesvirus in commercial bivalve in northern California, USA: conventional and quantitative PCR. Dis. Aquat. Organ. 94, 106-116. doi: 10.3354/dao02314

Burioli, E. A. V., Prearo, M., and Houssin, M. (2017). Complete genome sequence of Ostreid herpesvirus type $1 \mu$ Var isolated during mortality events in the Pacific oyster Crassostrea gigas in France and Ireland. Virology 509, 239-251. doi: 10.1016/j.virol.2017.06.027

Burioli, E. A. V., Prearo, M., Riina, M. V., Bona, M. C., Fioravanti, M. L., Arcangeli, G., et al. (2016). Ostreid herpesvirus type 1 genomic diversity in wild populations of Pacific oyster Crassostrea gigas from Italian coasts. J. Invertebr. Pathol. 137, 71-83. doi: 10.1016/j.jip.2016.05.004

Burioli, E. A. V., Varello, K., Lavazza, A., Bozzetta, E., Prearo, M., and Houssin, M. (2018). A novel divergent group of Ostreid herpesvirus $1 \mu$ Var variants associated with a mortality event in Pacific oyster spat in normandy (France) in 2016. J. Fish Dis. 41, 1759-1769. doi: 10.1111/jfd.12883

Callahan, L. N., Phelan, M., Mallinson, M., and Norcross, M. A. (1991). Dextran sulfate blocks antibody binding to the principal neutralizing domain of human immunodeficiency virus type 1 without interfering with gp120-CD4 interactions. J. Virol. 65, 1543-1550.

Clegg, T. A., Morrissey, T., Geoghegan, F., Martin, S. W., Lyons, K., Ashe, S., et al. (2014). Risk factors associated with increased mortality of farmed Pacific oysters in Ireland during 2011. Prev. Vet. Med. 113, 257-267. doi: 10.1016/j.prevetmed. 2013.10.023

Connolly, S. A., Whitbeck, J. J., Rux, A. H., Krummenacher, C., van Drunen Littelvan den Hurk, S., Cohen, G. H., et al. (2001). Glycoprotein D homologs in herpes simplex virus type 1, pseudorabies virus, and bovine herpes virus type 1 bind directly to human HveC(nectin-1) with different affinities. Virology 280, 7-18. doi: 10.1006/viro.2000.0747

Corbeil, S., Faury, N., Segarra, A., and Renault, T. (2015). Development of an in situ hybridization assay for the detection of ostreid herpesvirus type 1 mRNAs in the Pacific oyster, Crassostrea gigas. J. Virol. Methods 211, 43-50. doi: 10.1016/j.jviromet.2014.10.007

Da Silva, P. M., Renault, T., Fuentes, J., and Villalba, A. (2008). Herpesvirus infection in European flat oysters Ostrea edulis obtained from brood stocks of various geographic origins and grown in Galicia (NW Spain). Dis. Aquat. Organ. 78, 181-188. doi: 10.3354/dao01874

Davison, A. J., Eberle, R., Ehlers, B., Hayward, G. S., McGeoch, D. J., Minson, A. C., et al. (2009). The order herpesvirales. Arch. Virol. 154, 171-177. doi: 10.1007/s00705-008-0278-4

Davison, A. J., Trus, B. L., Cheng, N., Steven, A. C., Watson, M. S., Cunningham, C., et al. (2005). A novel class of herpesvirus with bivalve hosts. J. Gen. Virol. 86, 41-53. doi: 10.1099/vir.0.80382-0

Dégremont, L., Lamy, J.-B., Pépin, J.-F., Travers, M.-A., and Renault, T. (2015). New insight for the genetic evaluation of resistance to ostreid herpesvirus infection, a worldwide disease, in Crassostrea gigas. PLoS One 10:e0127917. doi: 10.1371/journal.pone.0127917

Domeneghetti, S., Varotto, L., Civettini, M., Rosani, U., Stauder, M., Pretto, T., et al. (2014). Mortality occurrence and pathogen detection in Crassostrea gigas and Mytilus galloprovincialis close-growing in shallow waters (Goro lagoon, Italy). Fish Shellfish Immunol. 41, 37-44. doi: 10.1016/j.fsi.2014.05.023

Dundon, W. G., Arzul, I., Omnes, E., Robert, M., Magnabosco, C., Zambon, M., et al. (2011). Detection of type 1 ostreid herpes variant (OsHV-1 $\mu$ var) with no associated mortality in French-origin Pacific cupped oyster Crassostrea gigas farmed in Italy. Aquaculture 314, 49-52. doi: 10.1016/j.aquaculture.2011. 02.005

Dyer, A. P., Banfield, B. W., Martindale, D., Spannier, D. M., and Tufaro, F. (1997). Dextran sulfate can act as an artificial receptor to mediate a type-specific herpes simplex virus infection via glycoprotein B. J. Virol. 71, 191-198.

Farooq, A. V., Valyi-Nagy, T., and Shukla, D. (2010). Mediators and mechanisms of herpes simplex virus entry into ocular cells. Curr. Eye Res. 35, 445-450. doi: $10.3109 / 02713681003734841$
Friedman, C. S., Estes, R. M., Stokes, N. A., Burge, C. A., Hargove, J. S., Barber, B. J., et al. (2005). Herpes virus in juvenile Pacific oysters Crassostrea gigas from Tomales Bay, California, coincides with summer mortality episodes. Dis. Aquat. Organ. 63, 33-41. doi: 10.3354/dao063033

Garcia, C., Thébault, A., Dégremont, L., Arzul, I., Miossec, L., Robert, M., et al. (2011). Ostreid herpesvirus 1 detection and relationship with Crassostrea gigas spat mortality in France between 1998 and 2006. Vet. Res. 42:73. doi: 10.1186/ 1297-9716-42-73

Green, T. J., Rolland, J.-L., Vergnes, A., Raftos, D., and Montagnani, C. (2015). OsHV-1 countermeasures to the Pacific oyster's anti-viral response. Fish Shellfish Immunol. 47, 435-443. doi: 10.1016/j.fsi.2015.09.025

Green, T. J., and Speck, P. (2018). Antiviral defense and innate immune memory in the oyster. Viruses 10:133. doi: 10.3390/v10030133

Grijalva-Chon, J. M., Castro-Longoria, R., Ramos-Paredes, J., Enríquez-Espinoza, T. L., and Mendoza-Cano, F. (2013). Detection of a new OsHV-1 DNA strain in the healthy Pacific oyster, Crassostrea gigas Thunberg, from the Gulf of California. J. Fish Dis. 36, 965-968. doi: 10.1111/jfd.12028

Huemer, H. P., Larcher, C., Dierich, M. P., and Falke, D. (1992). Factors influencing the interaction of herpes simplex virus glycoprotein $\mathrm{C}$ with the third component of complement. Arch. Virol. 127, 291-303. doi: 10.1007/BF01309591

Hwang, J. Y., Park, J. J., Yu, H. J., Hur, Y. B., Arzul, I., Couraleau, Y., et al. (2013). Ostreid herpesvirus 1 infection in farmed Pacific oyster larvae Crassostrea gigas (Thunberg) in Korea. J. Fish Dis. 36, 969-972. doi: 10.1111/jfd.12093

Jee, B. Y., Lee, S. J., Cho, M. Y., Lee, S. J., Kim, J. W., Choi, S. H., et al. (2013). Detection of Ostreid Herpesvirus 1 from Adult Pacific Oysters Crassostrea gigas Cultured in Korea. Available at: http://kpubs.org/article/articleMain.kpubs? articleANo=E1HKAL_2013_v16n2_131 (accessed July 23, 2015).

Jenkins, C., Hick, P., Gabor, M., Spiers, Z., Fell, S., Gu, X., et al. (2013). Identification and characterisation of an ostreid herpesvirus-1 microvariant (OsHV-1 $\mu$-var) in Crassostrea gigas (Pacific oysters) in Australia. Dis. Aquat. Organ. 105, 109-126. doi: 10.3354/dao02623

Jouaux, A., Lafont, M., Blin, J.-L., Houssin, M., Mathieu, M., and Lelong, C. (2013). Physiological change under OsHV-1 contamination in Pacific oyster Crassostrea gigas through massive mortality events on fields. BMC Genomics 14:590. doi: 10.1186/1471-2164-14-590

Karasneh, G. A., and Shukla, D. (2011). Herpes simplex virus infects most cell types in vitro: clues to its success. Virol. J. 8, 481. doi: 10.1186/1743-422X-8-481

Keeling, S. E., Brosnahan, C. L., Williams, R., Gias, E., Hannah, M., Bueno, R., et al. (2014). New Zealand juvenile oyster mortality associated with ostreid herpesvirus 1-an opportunistic longitudinal study. Dis. Aquat. Organ. 109, 231-239. doi: 10.3354/dao02735

Le Deuff, R. M., and Renault, T. (1999). Purification and partial genome characterization of a herpes-like virus infecting the Japanese oyster, Crassostrea gigas. J. Gen. Virol. 80(Pt 5), 1317-1322. doi: 10.1099/0022-1317-80-5-1317

Lynch, S. A., Carlsson, J., Reilly, A. O., Cotter, E., and Culloty, S. C. (2012). A previously undescribed ostreid herpes virus 1 (OsHV-1) genotype detected in the Pacific oyster, Crassostrea gigas, in Ireland. Parasitology 139, 1526-1532. doi: $10.1017 /$ S0031182012000881

Martenot, C., Lethuillier, O., Fourour, S., Oden, E., Trancart, S., Travaillé, E., et al. (2015). Detection of undescribed ostreid herpesvirus 1 (OsHV-1) specimens from Pacific oyster, Crassostrea gigas. J. Invertebr. Pathol. 132, 182-189. doi: 10.1016/j.jip.2015.10.005

Martenot, C., Oden, E., Travaillé, E., Malas, J. P., and Houssin, M. (2010). Comparison of two real-time PCR methods for detection of ostreid herpesvirus 1 in the Pacific oyster Crassostrea gigas. J. Virol. Methods 170, 86-89. doi: 10.1016/j.jviromet.2010.09.003

Martenot, C., Oden, E., Travaillé, E., Malas, J.-P., and Houssin, M. (2011). Detection of different variants of Ostreid Herpesvirus 1 in the Pacific oyster, Crassostrea gigas between 2008 and 2010. Virus Res. 160, 25-31. doi: 10.1016/j. virusres.2011.04.012

Martenot, C., Segarra, A., Baillon, L., Faury, N., Houssin, M., and Renault, T. (2016). In situ localization and tissue distribution of ostreid herpesvirus 1 proteins in infected Pacific oyster, Crassostrea gigas. J. Invertebr. Pathol. 136, 124-135. doi: 10.1016/j.jip.2016.04.002

Martenot, C., Travaillé, E., Lethuillier, O., Lelong, C., and Houssin, M. (2013). Genome exploration of six variants of the Ostreid Herpesvirus 1 and characterization of large deletion in OsHV-1 $\mu$ Var specimens. Virus Res. 178, 462-470. doi: 10.1016/j.virusres.2013.08.006 
Mello, D. F., Danielli, N. M., Curbani, F., Pontinha, V. A., Suhnel, S., Castro, M. A. M., et al. (2018). First evidence of viral and bacterial oyster pathogens in the Brazilian coast. J. Fish Dis. 41, 559-563. doi: 10.1111/jfd.12755

Morga, B., Faury, N., Guesdon, S., Chollet, B., and Renault, T. (2017). Haemocytes from Crassostrea gigas and OsHV-1: a promising in vitro system to study host/virus interactions. J. Invertebr. Pathol. 150, 45-53. doi: 10.1016/j.jip.2017. 09.007

Nakashima, H., Yoshida, O., Baba, M., De Clercq, E., and Yamamoto, N. (1989). Anti-HIV activity of dextran sulphate as determined under different experimental conditions. Antiviral Res. 11, 233-246. doi: 10.1016/01663542(89)90033-8

Nicolas, J.-L., Comps, M., and Cochennec-Laureau, N. (1992). Herpes-like virus infecting Pacific oyster larvae, Crassostrea gigas. Bull. Eur. Assoc. Fish Pathol. 12, $11-13$.

Oden, E., Martenot, C., Berthaux, M., Travaille, E., Malas, J. P., and Houssin, M. (2011). Quantification of ostreid herpesvirus 1 (OsHV-1) in Crassostrea gigas by real-time PCR: determination of a viral load threshold to prevent summer mortalities. Aquaculture 317, 27-31. doi: 10.1016/j.aquaculture.2011.04.001

Ohki, S., Arnold, K., Srinivasakumar, N., and Flanagan, T. D. (1991). Effect of dextran sulfate on fusion of Sendai virus with human erythrocyte ghosts. Biomed. Biochim. Acta 50, 199-206.

Paul-Pont, I., Dhand, N. K., and Whittington, R. J. (2013a). Influence of husbandry practices on OsHV-1 associated mortality of Pacific oysters Crassostrea gigas. Aquaculture 412-413, 202-214. doi: 10.1016/j.aquaculture.2013.07.038

Paul-Pont, I., Dhand, N. K., and Whittington, R. J. (2013b). Spatial distribution of mortality in Pacific oysters Crassostrea gigas: reflection on mechanisms of OsHV-1 transmission. Dis. Aquat. Organ. 105, 127-138. doi: 10.3354/dao02615

Paul-Pont, I., Evans, O., Dhand, N. K., Rubio, A., Coad, P., and Whittington, R. J. (2014). Descriptive epidemiology of mass mortality due to Ostreid herpesvirus1 (OsHV-1) in commercially farmed Pacific oysters (Crassostrea gigas) in the Hawkesbury River estuary. Aust. Aquac. 422-423, 146-159. doi: 10.1016/j. aquaculture.2013.12.009

Peeler, E. J., Reese, R. A., Cheslett, D. L., Geoghegan, F., Power, A., and Thrush, M. A. (2012). Investigation of mortality in Pacific oysters associated with Ostreid herpesvirus-1 $\mu$ Var in the Republic of Ireland in 2009. Prev. Vet. Med. 105, 136-143. doi: 10.1016/j.prevetmed.2012.02.001

Piret, J., Lamontagne, J., Bestman-Smith, J., Roy, S., Gourde, P., Désormeaux, A., et al. (2000). In vitro and in vivo evaluations of sodium lauryl sulfate and dextran sulfate as microbicides against herpes simplex and human immunodeficiency viruses. J. Clin. Microbiol. 38, 110-119.

Ramos-Kuri, M., Kretschmer, R. R., Espinosa-Larios, E. L., and Aguilar-Setién, A. (1990). In vitro and in vivo effect of heparin, chondroitin, dextran and protamine on the virulence of pseudorabies virus (Suid herpesvirus 1). Arch. Invest. Med. 21, 29-33.

Renault, T., Cochennec, N., Le Deuff, R. M., and Chollet, B. (1994). Herpes-like virus infecting Japanese oyster (C. gigas) spat. Bull. Eur. Assoc. Fish Pathol. 14, 64-66.

Renault, T., Faury, N., Barbosa-Solomieu, V., and Moreau, K. (2011). Suppression substractive hybridisation (SSH) and real time PCR reveal differential gene expression in the Pacific cupped oyster, Crassostrea gigas, challenged with Ostreid herpesvirus 1. Dev. Comp. Immunol. 35, 725-735. doi: 10.1016/j.dci. 2011.02.004

Renault, T., and Lipart, C. (1998). Diagnosis of Herpes-like Virus Infections in Oysters using Molecular Techniques. Available at: http://archimer.ifremer.fr/ doc/00000/2902/ (accessed May 6, 2013)

Renault, T., Moreau, P., Faury, N., Pepin, J.-F., Segarra, A., and Webb, S. (2012). Analysis of clinical ostreid herpesvirus 1 (malacoherpesviridae) specimens by sequencing amplified fragments from three virus genome areas. J. Virol. 86, 5942-5947. doi: 10.1128/JVI.06534-11

Roque, A., Carrasco, N., Andree, K. B., Lacuesta, B., Elandaloussi, L., Gairin, I., et al. (2012). First report of OsHV-1 microvar in Pacific oyster (Crassostrea gigas) cultured in Spain. Aquaculture 32, 303-306. doi: 10.1016/j.aquaculture.2011. 10.018

Rosani, U., Varotto, L., Domeneghetti, S., Arcangeli, G., Pallavicini, A., and Venier, P. (2014). Dual analysis of host and pathogen transcriptomes in ostreid herpesvirus 1-positive Crassostrea gigas. Environ. Microbiol. 17, 4200-4212. doi: $10.1111 / 1462-2920.12706$
Schikorski, D., Faury, N., Pepin, J. F., Saulnier, D., Tourbiez, D., and Renault, T. (2011a). Experimental ostreid herpesvirus 1 infection of the Pacific oyster Crassostrea gigas: kinetics of virus DNA detection by q-PCR in seawater and in oyster samples. Virus Res. 155, 28-34. doi: 10.1016/j.virusres.2010.07.031

Schikorski, D., Renault, T., Saulnier, D., Faury, N., Moreau, P., and Pepin, J. (2011b). Experimental infection of Pacific oyster Crassostrea gigas spat by ostreid herpesvirus 1: demonstration of oyster spat susceptibility. Vet. Res. 42:27. doi: 10.1186/1297-9716-42-27

Schols, D., Pauwels, R., Desmyter, J., and De Clercq, E. (1990). Dextran sulfate and other polyanionic anti-HIV compounds specifically interact with the viral gp120 glycoprotein expressed by T-cells persistently infected with HIV-1. Virology 175, 556-561. doi: 10.1016/0042-6822(90)90440-3

Segarra, A., Baillon, L., Faury, N., Tourbiez, D., and Renault, T. (2016). Detection and distribution of ostreid herpesvirus 1 in experimentally infected Pacific oyster spat. J. Invertebr. Pathol. 133, 59-65. doi: 10.1016/j.jip.2015.11.013

Segarra, A., Baillon, L., Tourbiez, D., Benabdelmouna, A., Faury, N., Bourgougnon, N., et al. (2014a). Ostreid herpesvirus type 1 replication and host response in adult Pacific oysters, Crassostrea gigas. Vet. Res. 45:103. doi: 10.1186/s13567014-0103-x

Segarra, A., Mauduit, F., Faury, N., Trancart, S., Dégremont, L., Tourbiez, D., et al. (2014b). Dual transcriptomics of virus-host interactions: comparing two Pacific oyster families presenting contrasted susceptibility to ostreid herpesvirus 1. BMC Genomics 15:580. doi: 10.1186/1471-2164-15-580

Segarra, A., Pépin, J. F., Arzul, I., Morga, B., Faury, N., and Renault, T. (2010). Detection and description of a particular Ostreid herpesvirus 1 genotype associated with massive mortality outbreaks of Pacific oysters, Crassostrea gigas, in France in 2008. Virus Res. 153, 92-99. doi: 10.1016/j.virusres.2010.07.011

Spear, P. G. (2004). Herpes simplex virus: receptors and ligands for cell entry. Cell. Microbiol. 6, 401-410. doi: 10.1111/j.1462-5822.2004.00389.x

Spear, P. G., and Longnecker, R. (2003). Herpesvirus entry: an update. J. Virol. 77, 10179-10185. doi: 10.1128/JVI.77.19.10179-10185.2003

Tiwari, V., Clement, C., Xu, D., Valyi-Nagy, T., Yue, B. Y. J. T., Liu, J., et al. (2006). Role for 3-O-sulfated heparan sulfate as the receptor for herpes simplex virus type 1 entry into primary human corneal fibroblasts. J. Virol. 80, 8970-8980. doi: 10.1128/JVI.00296-06

Vaheri, A. (2007). Heparin and related polyionic substances as virus inhibitors. 1964. APMIS Acta Pathol. Microbiol. Immunol. Scand. 115, 565-570; discussion 571-572. doi: 10.1111/j.1600-0463.2007.apm_686a.X

Whitbeck, J. C., Peng, C., Lou, H., Xu, R., Willis, S. H., Ponce de Leon, M., et al. (1997). Glycoprotein D of herpes simplex virus (HSV) binds directly to HVEM, a member of the tumor necrosis factor receptor superfamily and a mediator of HSV entry. J. Virol. 71, 6083-6093.

Whittington, R. J., Hick, P. M., Evans, O., Rubio, A., Alford, B., Dhand, N., et al. (2015). Protection of Pacific oyster (Crassostrea gigas) spat from mortality due to ostreid herpesvirus 1 (OsHV-1 $\mu$ Var) using simple treatments of incoming seawater in land-based upwellers. Aquaculture 437, 10-20. doi: 10.1016/j. aquaculture.2014.11.016

Yamada, H., Nagao, C., Haredy, A. M., Mori, Y., Mizuguchi, K., Yamanishi, K., et al. (2014). Dextran sulfate-resistant A/Puerto Rico/8/34 influenza virus is associated with the emergence of specific mutations in the neuraminidase glycoprotein. Antiviral Res. 111, 69-77. doi: 10.1016/j.antiviral.2014.09.002

Yamada, K., Noguchi, K., Nonaka, D., Morita, M., Yasuda, A., Kawazato, H., et al. (2012). Addition of a single N-glycan to street rabies virus glycoprotein enhances virus production. J. Gen. Virol. 94, 270-275. doi: 10.1099/vir.0. 047852-0

Conflict of Interest Statement: The authors declare that the research was conducted in the absence of any commercial or financial relationships that could be construed as a potential conflict of interest.

Copyright (C) 2019 Martenot, Faury, Morga, Degremont, Lamy, Houssin and Renault. This is an open-access article distributed under the terms of the Creative Commons Attribution License (CC BY). The use, distribution or reproduction in other forums is permitted, provided the original author(s) and the copyright owner(s) are credited and that the original publication in this journal is cited, in accordance with accepted academic practice. No use, distribution or reproduction is permitted which does not comply with these terms. 